\title{
Selection for Profit in Cattle: I. Economic Weights for Purebred Dairy Cattle in the Czech Republic
}

\author{
M. Wolfová, ${ }^{\star 1}$ J. Wolf, ${ }^{\star}$ J. Kvapilík, ${ }^{*}$ and J. Kica† \\ *Institute of Animal Science, PO Box 1, CZ 10401 Prague-Uhř́něves, Czech Republic \\ †Slovak Agriculture Research Center, Hlohovská 2, SK 94991 Nitra, Slovak Republic
}

\begin{abstract}
A bioeconomic model for dairy cattle production was used to estimate economic values of 18 traits for dairy sires in purebred Holstein and Czech Fleckvieh populations. Economic values were defined as partial derivatives of the profit function with respect to each trait in a closed production system with dairy cow herds and integrated fattening of bulls. All revenues and costs associated with cows calving in the herds within one year and with their progeny were discounted at 5\% per annum back to the date of calving. Calculations were carried out for the situation in the Czech Republic in 2005 (scenario 1: market quotas for milk yield and fat percentage) and for the expected situation in 2015 (scenario 2: free market). The relative economic importance of each trait was expressed as a ratio of the standardized economic value of that trait (its marginal economic value multiplied by its genetic standard deviation) to the standardized economic value of 305-d milk yield, with average fat and protein percentages. In addition to milk yield, somatic cell score was the second most important trait, achieving $32 \%$ to $43 \%$ of the value for milk yield in both scenarios. The relative importance of milk components differed notably between scenarios. The relative importance was approximately zero for protein and from -14 to $-23 \%$ for fat percentage in scenario 1, but changed to $38 \%$ for protein and 27 to $31 \%$ for fat percentage in scenario 2 . In both scenarios and for both breeds, the relative economic values for somatic cell score and length of productive life of cows were similar to those for fat and protein percentages in scenario 2 . The smallest relative economic values (less than $4 \%$ of the relative importance of milk yield) were for birth weight, conception rate of heifers, and carcass traits. In conclusion, relative emphasis among traits in the breeding objective for Czech dairy cattle
\end{abstract}

Received September 20, 2006.

Accepted January 15, 2007.

${ }^{1}$ Corresponding author: wolfova.marie@vuzv.cz should be reassessed according to the expected situation after shifting to a free market economy in 2015 .

Key words: economic weight, purebreeding

\section{INTRODUCTION}

To maximize genetic improvement, selection must be directed toward an appropriate breeding goal. As the agricultural policy of the European Union has come to focus on market liberalization and decreasing compensation to farmers, producer revenues from sales of milk and beef have declined, and profitability of farming enterprises with dairy or dual-purpose cows has become more dependent on minimizing the cost of production. Improving animals for so-called functional traits is one way to reduce costs. Cattle breeders outside Scandinavia have been somewhat reluctant to include functional traits in selection programs. Presently, however, breeding goals of many countries and many breeds incorporate health, longevity, and fertility traits (Miglior et al., 2005).

Although some correlated improvement in health and life span may be obtained by selection for indirect measurements (e.g., SCC or linear type traits; Boettcher et al., 1998; Cranford and Pearson, 2001), the direct inclusion of disease incidence and length of productive life into the recording system, genetic evaluations, and selection decisions can bring extra economic benefit (Heringstad et al., 2003; Philipsson and Lindhé, 2003).

For the definition of an economic breeding goal and for the construction of selection indices, not only genetic parameters, but also economic values for traits are required. Because economic values computed from different investigations are generally not compatible (Reinsch and Dempfle, 1998), it is beneficial to evaluate all traits to be used in a breeding program jointly using the same methodology.

Wolfová et al. (2001) estimated economic values for production and reproduction traits and for productive life of Holstein and Czech Fleckvieh cows in the Czech Republic. After entry into the European Union in 2004, however, legislative and macro- as well as microeconomic conditions have changed substantially for dairy 
farmers. Economic values of cattle production traits are sensitive to circumstances that change over the time horizon of a breeding program (Groen, 1990). In addition, future breeding goals must consider traits associated with animal welfare, such as longevity and health, because ignoring these will reduce farm profit, increase the environmental impact of dairy farming, and diminish consumer demand for animal products (Olesen et al., 2000; Stott et al., 2005). Estimated breeding values for SCS have been available in the Czech Republic since 2006 , and research is in progress for genetic evaluation of clinical mastitis (CM; Wolfová et al., 2006) and cow survival (Páchová et al., 2005). All of these circumstances make reestimation of the economic values of traits for Czech dairy populations timely and relevant.

The aim of this study is therefore to estimate economic values for traditional and new traits of Czech dairy cattle populations. New traits include SCS, CM incidence, calving difficulty score, and calf survival. For this purpose, a new bioeconomic model for dairy production systems will be applied to the situation in the Czech Republic in 2005 (market quotas for milk yield and fat percentage) and another for the expected situation in 2015 (free market).

\section{MATERIALS AND METHODS}

\section{The Bioeconomic Model for the Dairy Production System}

The derivation of economic values was based on a bioeconomic model, the basic features of which were described by Wolfová et al. (2005). A classical indoor production system with dairy or dual-purpose cows producing milk plus the integrated intensive indoor fattening of surplus progeny was simulated in the model. Management of the system and herd characteristics were chosen to represent current commercial practices on dairy farms and fattening enterprises in the Czech Republic. Cows are kept in a loose-housing system and calving is equally distributed over the whole year. All matings are by AI. Cows not pregnant after a given number of inseminations are culled at the end of their current lactation. A maximum of 10 lactations is allowed per cow. All calves are reared together until 180 $d$ of age. Female calves are kept for replacement or for sale, preferably as breeding animals. Heifers are mated when they reach an optimal proportion of mature cow weight. Heifers with unsuitable conformation or with health problems during the rearing period and heifers not pregnant after a given number of inseminations are sold for slaughter. Surplus heifer calves that are in calf but not required to maintain herd size are sold at $7 \mathrm{mo}$ of pregnancy. A proportion of male calves are sold as breeding animals to AI stations. All surplus male calves are fattened to a fixed slaughter weight and marketed.

The model included both deterministic and stochastic components. Performance for most traits was simulated as the population average, but variation in several traits was taken into account. Carcass quality, for example, was assigned by sampling from the distribution of commercial grading classes, assuming an underlying normal distribution. Milk yield, fat percentage, protein percentage, and SCS were assumed to be normally distributed, with known means and standard deviations. The model was noninteger (fractions of animals were allowed), and herd size was considered to be the fixed number of cows calving per year. When applying limitations to the outputs (a scenario in which quotas for milk yield and fat percentage were imposed), the number of cows was rescaled prior to calculating the economic values.

Structure of the Cow Herd. The cow herd structure was derived as the stationary state of a Markov chain (Reinsch and Dempfle, 1998). Herd dynamics were described in terms of possible categories for the animals and probabilities of transitions among them. Each cow category was a combination of 2 variables: the sequential number of the reproduction cycle and the developmental state of the cow within that cycle. The 5 possible cow states were: 1) cow died within the given reproduction cycle, 2) cow culled between calving and start of mating because of health problems following dystocia, 3) cow culled within the reproduction cycle for low milk production or for health problems other than dystocia, 4) cow culled after lactation because she did not become pregnant, and 5) cow was pregnant entering the next reproduction cycle (only for lactations 1 to 9 ). The total number of cow categories was therefore $9 \times 5+4=49$.

For the progeny, 13 categories were defined. The categories for calves were 1) stillborn calves, 2) calves that died within $48 \mathrm{~h}$ after birth, 3) calves that died from $48 \mathrm{~h}$ after birth through the end of the rearing period, and 4) male calves sold as breeding animals. Replacement heifers were divided into the following groups: 1) heifers that died between the end of the rearing period up until calving, 2) heifers rejected as herd replacements before their first mating because of poor health or unsatisfactory confirmation, 3) heifers slaughtered because they did not become pregnant, 4) heifers sold pregnant, and 5) pregnant heifers that entered the herd. The categories for fattened bulls were 1) bulls that died during the fattening period, 2) bulls culled for health problems before reaching target slaughter weight, and 3) bulls slaughtered at the target slaughter weight. 


\section{Traits}

Traits that are assumed to influence profit were assigned to 4 groups.

Milk Production Traits. Milk yield for 305 d, fat percentage, and protein percentage were assigned to this group.

Growth Traits. Growth traits included birth weight, $\mathrm{ADG}$ of calves from birth to the end of the rearing period, $\mathrm{ADG}$ of heifers from the end of the rearing period to first mating and from first mating to calving, ADG of bulls during the fattening period, and mature weight, which was defined as cow weight after the third calving.

Carcass Traits. Dressing percentage and average class for fleshiness and fat covering based on the SEUROP carcass grading system were used. In this grading system, there are 6 classes for fleshiness $(\mathrm{S}, \mathrm{E}, \mathrm{U}, \mathrm{R}$, $\mathrm{O}, \mathrm{P})$, where $\mathrm{S}$ is the best class and $\mathrm{P}$ is the worst class. For calculation of the economic value for fleshiness, the numerical values 1 to 6 were inserted for $\mathrm{S}$ to $\mathrm{P}$. For fat covering, 5 classes ( 1 to 5 ) were distinguished.

Functional Traits. The traits belonging to this group were average score for calving difficulty, conception rate of heifers, conception rate of cows, calf mortality at birth, calf mortality during the rearing period, length of productive life of cows, SCS, and incidence of $\mathrm{CM}$ cases per cow per year. Calving difficulty score was expressed as the average class for calving difficulty $(1=$ easy calving without assistance, 2 = easy calving with assistance of 1 or 2 persons, $3=$ difficult calving with assistance of more than 2 persons or with veterinary assistance, and $4=$ cesarean section). Scores 3 and 4 constituted the definition of dystocia. The conception rate of heifers and cows was defined as the proportion of animals that conceived in one mating period in comparison with the number of animals mated. Calf mortality at birth included abortions, stillborn calves, and calves dying within $48 \mathrm{~h}$ after birth. Calf mortality at birth was expressed as the average number of dead calves per calving.

The length of productive life (in years) was defined as the time from first calving of a heifer to the time of her culling or death. The SCS was calculated from the SCC, which was defined as the average number of somatic cells per milliliter of milk:

$$
S C S=\log _{2}\left(\frac{S C C}{100,000}\right)+3 .
$$

Clinical mastitis incidence was defined as the average number of CM cases per cow at risk in the herd per year.

\section{Economic Efficiency of the Production System}

Profit (i.e., the difference between the present values of revenues and costs per cow and year at the stationary state of herd structure) was the criterion of economic efficiency for the modeled production system:

$$
\text { proft }=\operatorname{rev}^{\prime} \mathbf{N D E}^{[\operatorname{rev}]}-\operatorname{cost}^{\prime} \mathbf{N D E}^{[\cos t]},
$$

where rev' $^{\prime}$ and cost' are the row vectors of revenues and costs, respectively, per animal, the elements of which are $r e v_{i}$ and $\operatorname{cost}_{i}$, with $i$ being the category of animals; and $\mathbf{N D E}^{[\mathbf{r e v}]}$ and $\mathbf{N D E}^{[\mathbf{c o s t}]}$ are the column vectors of the number of discounted expressions connected with revenues and costs, respectively, the elements of which are $N D E_{l}^{[r e v]}$ and $N D E_{l}^{[c o s t]}$. Equations for calculation of the numbers of discounted expressions are given in Wolfová et al. (2005).

Using this approach, all revenues and costs occurring in the cow herd during a year and in the life of progeny born in the herd that same year were discounted to the date of calving (birth of progeny). The life of progeny covered the time from birth to slaughter, death, sale, or the first calving of heifers. Note that the number of discounted expressions in equation [1] includes only one generation of progeny.

Revenues. Revenues came from fattened bulls, culled cows and heifers, sold breeding heifers and bulls, milk, and manure. Revenues from slaughtered or culled animals of category $i$ were calculated as

$$
R S L_{i}=L W_{i} D P_{i} k_{D P i} P R_{i} k_{P R i},
$$

where $L W_{i}$ is live weight at slaughter or culling, $D P_{i}$ is the dressing percentage, $P R_{i}$ is the average price received per kilogram of carcass weight, and $k_{D P i}$ and $k_{P R i}$ are coefficients for the decreased dressing percentage and average price of animals slaughtered prior to reaching the target slaughter weight, respectively. For animals slaughtered at the target weight, these coefficients equal 1.

The average price per kilogram of carcass depended on the distribution of carcasses over the commercial carcass grading classes for fleshiness and fat covering. An underlying normal distribution was assumed for both traits. For details of the calculation, see Wolfová et al. (1995, 2005).

Revenues from milk $\left(R e v_{\text {milk }}\right)$ were calculated as follows:

$$
\begin{gathered}
\operatorname{Rev}_{\text {milk }}=\text { Milk }_{\text {total }} \text { Price }_{\text {milk }} \\
\operatorname{Milk}_{\text {total }}=365 \sum_{i} \sum_{j_{i}} \text { Milk }_{i j_{i} p_{i j}} / C I_{i} \\
\operatorname{Milk}_{i j_{i}}=\sum_{t=1} \operatorname{Milk}_{i}(t) \\
\operatorname{Milk}(t)=a t^{b} e^{-c t} e^{-d p(t)},
\end{gathered}
$$


where Milk $_{\text {total }}$ is the average total milk production in kilograms per cow and year; Price $_{\text {milk }}$ is the average price per kilogram of milk; $M_{i l k_{i j}}$ is the milk produced by a cow in state $j_{i}$ of reproduction cycle $i$ (in kilograms); $p_{i j_{i}}$ is the proportion of cows in state $j_{i}$ of reproduction cycle $i ; C I_{i}$ is the calving interval in reproduction cycle $i$ (in days); $D_{i j_{i}}$ is the length of the lactation for a cow in state $j_{i}$ of reproduction cycle $i$ (in days); $\operatorname{Milk}(t)$ is the milk production (in kilograms) on day $t$ in milk in reproduction cycle $i$ calculated from the modified Wood function (Fox et al., 1990); $a, b, c, d$ are parameters for the lactation curve; and $p(t)$ is days in pregnancy as a function of DIM. The average milk price was calculated by considering its fat and protein percentages and the proportions of milk in the individual quality classes according to the SCC.

Costs. Costs were calculated separately for feeding, housing, breeding, and health. All other costs (labor, interest rate paid on capital investments, energy, repairs, insurance, and overhead) were accounted for as fixed costs per animal of each category per day. Although these costs are called "fixed" in the model, their sum is variable insofar as levels of various traits influenced the number of animals in each category and the length of the fattening period. Thus, alternative uses of saved production factors (e.g., a shorter fattening phase because of increased growth rate) are possible. On the other hand, increasing, for example, the survival rate of fattening animals would require more fattening places and would result in higher total fixed costs. The production system is seen from a long-run perspective in that breeding is a slow process, and there would be time to readjust farm management to provide scarce "fixed" inputs.

Feeding costs were calculated on the basis of daily net energy and protein requirements of animals and from the price for feed with given DM, net energy, and protein contents. Daily net energy and protein met requirements for maintenance, growth, lactation, and pregnancy. The equations used for the calculation of daily net energy and protein requirements for different animal categories were taken from Fox et al. (1990), Vencl et al. (1991), AFCR (1993), and Petrikovič and Sommer (2002). Feed costs included costs for water.

Housing costs were those for bedding (cost for straw minus revenue for manure). Breeding costs were costs for $\mathrm{AI}$ and included the price for semen, labor, and services per conception.

Health costs included veterinary costs that were expressed per animal (they did not change with alterations of the fattening or rearing periods), dystocia cost expressed per calving, and cost for removing and rendering dead animals. The dystocia cost depended on proportions of total calvings in each calving score class and on veterinary and labor costs specific to those scores. Health costs in the dairy production system were also related to incidence of $\mathrm{CM}$ in the herd. These costs were calculated as the total direct financial losses from CM per cow and year (see Wolfová et al., 2006, for details). Income loss caused by permanent yield reduction following mastitis in the current lactation (as reported by Houben et al., 1993, for example), losses from culling cows because of mastitis, and the correlated change in SCS were not included in the calculation to avoid double counting, because milk production, cow longevity, and SCS are individually included in the breeding goal.

\section{Calculation of Marginal Economic Values of Traits}

The marginal economic value of trait $l\left(e v_{l}\right)$ was defined as the partial derivative of the profit function with respect to that trait:

$$
e v_{l}=\left.\frac{\partial p r o f i t}{\partial T V_{l}}\right|_{T V_{l}=T V_{l}},
$$

where profit is the profit per cow and year, $T V_{l}$ is the value of the given trait, and $T V_{l_{a v}}$ is the trait mean in the population. In the calculations, the partial derivative was approximated by the difference quotient. The difference was set to $\pm 0.5 \%$ of the trait mean. The program package ECOWEIGHT (Wolf et al., 2005) was used for all calculations.

For calculating the economic value of growth rate in any time period, growth within that period was assumed to be linear, and growth rates in the previous and the following periods were held constant. The economic values of all growth traits were dependent on feed cost because neither feed intake nor feed conversion were included as separate traits.

An underlying normal distribution was assumed for fleshiness, fat covering class, calving difficulty score, fat percentage, and protein percentage. A log-normal distribution was assumed for SCS. The approach described by Wolfová et al. (1995) was applied for the calculation of economic values of these traits. The principle of the method is to shift the underlying distribution to the right and the left by multiplying the mean with the factors 1.005 and 0.995 . The new means in the original distributions are then determined and used for the calculation of economic weights. Only a change in revenue from slaughtered animals was taken into account when calculating economic values for fleshiness, fat covering, and dressing percentage. The economic value for calving difficulty score was affected not only by veterinary and labor costs, but also by its impact 
on calf and cow mortality and on the subsequent conception rate of cows as well. To avoid double counting, the conception rate of cows and the survival rate of calves were defined as the average of these traits only for those cows with easy calving. The conception rate of cows with dystocia was then expressed as a proportion of the conception rate of cows with easy calving. When calculating the economic value of cow conception rate, the conception rate in both groups of cows was changed, keeping the calving difficulty constant. When calculating the economic value of the calving difficulty score, only the number of cows with dystocia changed while the conception rate in both groups of cows remained constant. The same principle was used for calculating the economic value for calf mortality at birth.

The effect of dystocia on milk yield caused by the direct effect of mated bulls was not included into the economic value of calving difficulty score because data to evaluate the impact of different calving scores on subsequent milk production were not available. A change in the calving difficulty score influenced the number of weaned calves as well as the age structure of the cow herd. Consequently, the calving difficulty score affected revenues and costs in all animal categories.

The economic value for length of productive life of cows included the effect of changes in the culling rate for health problems other than dystocia. Calculating this economic value, the culling rates for low milk production, dystocia, failure to conceive, and management reasons were held constant. The effect of a prolonged length of productive life (change in age structure of the cow herd) on milk yield, however, was taken into account.

The benefits of improved conception rate of heifers and cows are a larger number of surplus heifers and a lower culling rate of nonpregnant females. Changes in the average score for calving difficulty, cow losses, or conception rate of cows altered the herd structure (a new stationary state is calculated after changing any of these traits), but the size of the cow herd remained constant.

Economic Values in a Situation with Milk Quotas. For calculating economic values under the situation with quotas, the total annual profit in the production system (Tprofit) was written as

$$
\text { Tprofit }=n_{\text {cow }} \text { profit },
$$

where $n_{\text {cow }}$ is the number of cows. If there is a milk quota, the total amount of milk is assumed to stay constant, so any increase in milk yield per cow is then reflected by a decrease in the number of cows. We can write $e v_{l}=\left.\frac{1}{n_{\text {cow }}} \frac{\partial T \text { profit }}{\partial T V_{l}}\right|_{T V_{l}=T V_{\text {lav }}}=\frac{1}{n_{\text {cow }}} \frac{\partial n_{\text {cow }}}{\partial T V_{l}}$ profit $+\frac{\partial p r o f i t}{\partial T V_{l}}$.

The first term in the equation $\left(1 / n_{\text {cow }} \partial n_{\text {cow }} / \partial T V_{l}\right.$ profit) is zero for all traits for which a change of value has no influence on the total amount of milk and therefore on the number of cows. The second term in the equation $\left(\partial p r o f i t / \partial T V_{l}\right)$ is the economic value of trait $l$ in a situation without a milk quota. For those traits for which a change increases milk production, the first term in the equation (the change in the number of cows) is negative. Thus, when profit is positive, the economic values of these traits are always smaller in a situation with a milk quota than in a situation without a quota.

If there is a market quota for fat percentage, the only impact is on the calculation of the economic weight for milk fat percentage. A change in the fat percentage must be counterbalanced by a change in the number of cows.

Relative Economic Values. For a better comparison of the relative importance of different traits in the scenarios considered, the marginal economic values $\left(e v_{l}\right)$ were standardized by first multiplying them by the genetic standard deviation of each respective trait $\left(s_{l}\right)$. These standardized economic values were then expressed as percentages of the standardized economic value of $305-\mathrm{d}$ milk yield $\left(e v_{\text {milk }} s_{\text {milk }}\right)$. The relative economic value for trait $l\left(e v r_{l}\right)$ is therefore

$$
e v r_{l}=100 e v_{l} s_{l} / e v_{m i l k} s_{m i l k}
$$

\section{Input Data for the Calculation of Economic Values}

Economic values were calculated for 2 scenarios, the situation characterized by economic and production circumstances in the Czech Republic in the year 2005, and for the situation expected in 2015.

Scenario 1. For scenario 1, market quotas for milk yield and fat percentage were assumed. Productive and reproductive characteristics for both the Holstein and Czech Fleckvieh populations came from the annual reports of the Czech cattle breeders associations (Kvapilík et al., 2006). Mastitis data originated from Wolfová et al. (2006). All these data, including the genetic standard deviations of the traits, are summarized in Tables 1 and 2.

Carcass prices according to the SEUROP grading system were taken from the State Agricultural Intervention Fund of the Czech Republic (SZIF, 2006). Table 3 has coefficients by which the base price is multiplied for class combinations of fleshiness and fat covering. For the distribution of carcasses over the SEUROP classes, values published by Roffeis and Brudel (2003) were used. These values are given in Table 4 only for bulls 
Table 1. Means and genetic standard deviations ${ }^{1}$ of traits for both scenarios ${ }^{2}$ for Holsteins $(\mathrm{H})$ and Czech Fleckviehs $(\mathrm{F})^{3}$

\begin{tabular}{|c|c|c|c|c|}
\hline \multirow[b]{2}{*}{ Trait } & \multicolumn{2}{|l|}{$\mathrm{H}$} & \multicolumn{2}{|l|}{$\mathrm{F}$} \\
\hline & Mean & $\sigma_{a}$ & Mean & $\sigma_{a}$ \\
\hline 305-d milk yield, ${ }^{4} \mathrm{~kg}$ & $7,200(8,000)$ & 656 & $5,700(6,500)$ & 509 \\
\hline Milk fat percentage, $\%$ & $3.85(3.50)$ & 0.22 & $4.05(4.00)$ & 0.23 \\
\hline Milk protein percentage, $\%$ & $3.26(3.20)$ & 0.09 & $3.42(3.45)$ & 0.11 \\
\hline SCS & 4.52 & 0.085 & 4.52 & 0.086 \\
\hline Clinical mastitis incidence, cases/cow-year & 0.98 & 0.08 & 0.79 & 0.064 \\
\hline Calving difficulty, score & 1.33 & 0.06 & 1.08 & 0.05 \\
\hline Calf mortality at birth, $\%$ & $7.1(7.0)$ & 2.5 & 6.1 & 2.1 \\
\hline Calf mortality in rearing, $\%$ & 6.0 & 2.0 & 6.0 & 2.0 \\
\hline Conception rate of heifers, $\%$ & 95.0 & 1.5 & $96.9(97.0)$ & 1.5 \\
\hline Conception rate of cows, $\%$ & 91.0 & 2.0 & $92.1(92.4)$ & 2.0 \\
\hline Length of productive life of cows, yr & $2.74(2.91)$ & 0.30 & 3.41 & 0.30 \\
\hline Birth weight of calves, ${ }^{5} \mathrm{~kg}$ & 35 & 1.6 & 36.5 & 1.6 \\
\hline Mature weight of cows, kg & $615(640)$ & 17.5 & $630(655)$ & 17.5 \\
\hline Daily gain in the rearing period of calves ${ }^{5} \mathrm{~g} / \mathrm{d}$ & 800 & 60 & 800 & 60 \\
\hline Daily gain in fattening, ${ }^{5} \mathrm{~g} / \mathrm{d}$ & $750(800)$ & 47 & $750(850)$ & 47 \\
\hline Dressing percentage, ${ }^{6} \%$ & 52 & 1.14 & 54 & 1.14 \\
\hline Fleshiness ${ }^{6}$ class & 5.10 & 0.03 & 4.10 & 0.03 \\
\hline Fat covering, ${ }^{6}$ class & 3.12 & 0.02 & 2.84 & 0.02 \\
\hline
\end{tabular}

${ }^{1}$ Genetic standard deviations were taken from investigations on Czech cattle populations if available (Dědková and Wolf, 2001; Hradecká, 2002; Přibyl et al., 2004; Dědková, 2005, personal communication) or from the literature (Reinsch, 1993; Sölkner et al., 2000; Wünsch and Bergfeld, 2001).

${ }^{2}$ Scenario 1: current situation in the Czech Republic (2005); scenario 2: expected situation in 2015.

${ }^{3}$ Values for scenario 2 are given in parentheses when different from scenario 1 . The genetic standard deviations were assumed to be equal in both scenarios.

${ }^{4}$ Milk with given average fat and protein percentages.

${ }^{5}$ Values are given for female animals; economic values include both sexes.

${ }^{6}$ Values are given for heifers; economic values include all cattle categories (heifers, bulls, and cows).

as an example, but the distributions for heifers and cows were also taken into account in the calculations.

Cow culling rates for low milk production were assumed to be $0.15,0.12,0.10,0.05,0.05,0.03,0.02,0.02$,
0.0 , and 0.0 for Holsteins in reproduction cycles 1 to 10, respectively. The corresponding values for Czech Fleckvieh were $0.12,0.18,0.10,0.08,0.08,0.05,0.05$, $0.03,0.0$, and 0.0 . Values for other important manage-

Table 2. Characteristics of the cow herd structure for Holsteins $(H)$ and Czech Fleckviehs $(F)$ for both scenarios $^{1}$

\begin{tabular}{|c|c|c|}
\hline Characteristic & $\mathrm{H}$ & $\mathrm{F}$ \\
\hline Mortality rate of cows per reproduction cycle, ${ }^{2} \%$ & 1 & 1 \\
\hline Abortion rate of cows in reproduction cycle $1, \%$ & 3 & 3 \\
\hline Abortion rate of cows in reproduction cycles $\geq 2, \%$ & 2 & 2 \\
\hline Stillbirth rate $(\%)$ after easy calving ${ }^{3}$ in reproduction cycle 1 & 2 & 2 \\
\hline Stillbirth rate $(\%)$ after easy calving ${ }^{3}$ in reproduction cycles $\geq 2$ & 1 & 1 \\
\hline Stillbirth rate $(\%)$ after dystocia ${ }^{3}$ in all cycles & 20 & 20 \\
\hline \multicolumn{3}{|l|}{ Live-born calves after easy calving died within 48 h, \% } \\
\hline Reproduction cycle 1 & 2 & 2 \\
\hline Reproduction cycles $\geq 2$ & 1 & 1 \\
\hline \multicolumn{3}{|l|}{ Live-born calves after dystocia died within $48 \mathrm{~h}, \%$} \\
\hline Reproduction cycle 1 & 50 & 50 \\
\hline Reproduction cycles $\geq 2$ & 20 & 20 \\
\hline \multicolumn{3}{|l|}{ Proportion of dystocia when female calf is born, \% } \\
\hline Reproduction cycle 1 & 4.2 & 3.0 \\
\hline Reproduction cycles $\geq 2$ & 2.8 & 1.5 \\
\hline \multicolumn{3}{|l|}{ Proportion of dystocia when male calf is born, $\%$} \\
\hline Reproduction cycle 1 & 6.4 & 5.2 \\
\hline Reproduction cycles $\geq 2$ & 4.2 & 2.6 \\
\hline
\end{tabular}

${ }^{1}$ Scenario 1: current situation in the Czech Republic (2005); scenario 2: expected situation in 2015.

${ }^{2}$ Reproduction cycle means the interval between 2 subsequent calvings.

${ }^{3}$ Easy calving includes calving scores 1 and 2; dystocia includes calving scores 3 and 4 . 
Table 3. Price coefficients for each combination of fleshiness and fat covering classes ${ }^{1}$

\begin{tabular}{lccccc}
\hline \multirow{2}{*}{$\begin{array}{l}\text { Fleshiness } \\
\text { class }\end{array}$} & \multicolumn{5}{c}{ Fat covering class } \\
\cline { 2 - 6 } & 1 & 2 & 3 & 4 & 5 \\
\hline $\mathrm{S}(1)$ & 1.000 & 0.985 & 0.970 & 0.940 & 0.875 \\
$\mathrm{E}(2)$ & 0.960 & 0.945 & 0.925 & 0.890 & 0.820 \\
$\mathrm{U}(3)$ & 0.925 & 0.910 & 0.890 & 0.860 & 0.790 \\
$\mathrm{R}(4)$ & 0.875 & 0.860 & 0.840 & 0.805 & 0.730 \\
$\mathrm{O}(5)$ & 0.775 & 0.785 & 0.795 & 0.760 & 0.685 \\
$\mathrm{P}(6)$ & 0.655 & 0.675 & 0.675 & 0.640 & 0.565 \\
\hline
\end{tabular}

${ }^{1}$ The price per kilogram of carcass is calculated by multiplying the base price with the coefficient given in this table. The coefficients are the same for both breeds and both scenarios. Scenario 1: current situation in the Czech Republic (2005); scenario 2: expected situation in $2015 . \mathrm{S}=$ best class; $\mathrm{P}=$ worst class.

ment variables are shown in Table 5. Economic parameters for the calculation of revenues and costs are summarized in Tables 6 and 7.

There were big differences in milk payment systems among Czech dairies. Most gave little attention to milk components. For the given calculations, a simplified milk pricing system was used according to the proposal of Kvapilík (2005). There was a base price of 26.79 cents/ $\mathrm{kg}$ paid for milk volume and bonuses of 0.18 cents and 0.36 cents per each per cent of milk fat and milk protein, respectively ( $€ 1=100$ cents). The resultant price for any given fat and protein percentage was paid when the SCC was between 250,000 and 400,000 cells $/ \mathrm{mL}$ of milk. For lower SCC, a bonus of 0.54 cents $/ \mathrm{kg}$ of milk was paid, but when SCC was greater than 400,000, a fixed price of 7.14 cents/kg of milk was set. Other prices and costs corresponded to the situation in the Czech Republic in 2005.

Scenario 2. This scenario was based on changes expected in the agricultural policy of the European Union toward a more liberal market situation. Milk prices in all member states of the European Union are expected to decrease by 10 to $15 \%$ in 2015 for the following rea-

Table 4. Proportion (in \%) of bull carcasses in commercial classes for fleshiness and fat covering ${ }^{1}$

\begin{tabular}{lccccc}
\hline \multirow{2}{*}{$\begin{array}{l}\text { Fleshiness } \\
\text { class }\end{array}$} & \multicolumn{5}{c}{ Fat covering class } \\
\cline { 2 - 6 } & 1 & 2 & 3 & 4 & 5 \\
\hline $\mathrm{S}(1)$ & & & & & \\
$\mathrm{E}(2)$ & & $0.0 / 0.8$ & $0.0 / 0.7$ & & \\
$\mathrm{U}(3)$ & $0.8 / 6.4$ & $0.7 / 5.0$ & & \\
$\mathrm{R}(4)$ & $0.0 / 1.3$ & $6.4 / 57.8$ & $5.0 / 15.2$ & $0.0 / 0.3$ & \\
$\mathrm{O}(5)$ & $0.3 / 4.7$ & $42.8 / 5.5$ & $31.2 / 1.3$ & $0.3 / 0.0$ & \\
$\mathrm{P}(6)$ & $0.7 / 0.0$ & $8.5 / 0.0$ & $3.3 / 0.0$ & & \\
\hline
\end{tabular}

${ }^{1}$ The first number is for Holsteins, the second number is for Czech Fleckviehs. Empty cells mean that values are zero for both breeds. The distribution is assumed to be equal for both scenarios. Scenario 1: current situation in the Czech Republic (2005); scenario 2: expected situation in 2015 . $\mathrm{S}=$ best class; $\mathrm{P}=$ worst class. sons: 1) removal of milk quotas assumed for that year (Sonnleitner, 2006); 2) decreased economic compensation to farmers; 3) decreased intervention prices for butter and dry milk; 4) removal of export compensation; 5) decreased import duties; and 6) some increase in milk production. Using the same pricing system as in 2005 but with greater emphasis on milk components, the price for milk carrier is expected to be 1.79 cents $/ \mathrm{kg}$, the fat price 2.14 cents $/ \%$, and the protein price 4.29 cents $/ \%$ in scenario 2. Increased consumer attention to milk quality is expected to raise the bonus for low SCC (below 250,000 cells $/ \mathrm{mL}$ ) to 0.71 cents/kg of milk and to decrease the price for nonstandard milk (above 400,000 cell $\mathrm{s} / \mathrm{mL}$ ) to 3.57 cents $/ \mathrm{kg}$.

Under the unfavorable development of beef meat production in the European Union as well as in the Czech Republic (decreasing the self-supporting rate of beef under $100 \%$ ), beef prices are not expected to decline. Therefore, the same prices per kilogram of slaughter weight of all cattle categories as in scenario 1 were set for scenario 2 except for heifers, for which an $8 \%$ increase in carcass price is expected. An increase in productivity and yield of crop production also is expected. Therefore, the prices for rations were lowered by about $8 \%$ in scenario 2 relative to scenario 1 .

Expected trait levels in 2015 were predicted from current genetic trends but assuming changes for some traits because of inclusion of functional traits in selection indices of both breeds since 2005. Further, increases in milk production will decrease fat and protein percentages of milk and increase mature weight of cows. Because of higher milking costs, fixed costs will increase by about 10\% in Holsteins and by 5\% in Czech Fleckviehs. A continuous deterioration in health traits is expected; therefore, culling for health was increased by $5 \%$ in scenario 2 over scenario 1. In Holstein cows, a decrease in culling rate for low milk production equal to the above-mentioned increase in culling for health was made to ensure enough heifers for replacement. A small increase in fattening performance was expected as well. The parameters in scenario 2 that differ from those in scenario 1 are shown in parentheses in Tables 1 to 7 .

\section{RESULTS}

For both scenarios and both breeds, cow herd structure, calculated as the stationary state of a Markov chain, is shown in Table 8. Scenario 1 results for both breeds were similar to structures presented in the annual reports of the Czech cattle breeders associations (Kvapilík et al., 2006). The average number of calvings per cow was low in Holsteins (2.74) and somewhat greater in Czech Fleckvieh (3.41). The expected in- 
Table 5. Management variables for Holsteins (H) and Czech Fleckviehs (F) for both scenarios ${ }^{1}$

\begin{tabular}{lcr}
\hline Variable & $\mathrm{H}$ & $\mathrm{F}$ \\
\hline Average interval between calving and first insemination, d & 100 & 87 \\
Number of days dry, d & 65 & 60 \\
Maximal number of inseminations per cow or heifer & 4 & 4 \\
Weight of heifers at first insemination, kg & 400 & 420 \\
Length of the rearing period of calves, d & 180 & 180 \\
Age of pregnant heifers at selling, d & 660 & 660 \\
Slaughter weight of bulls in fattening, kg & $550(600)$ & $570(600)$ \\
Slaughter weight of heifers in fattening, kg & 450 & 450 \\
Proportion of reared male calves sold as breeding animals, \% & 1.0 & 0.5 \\
\hline
\end{tabular}

${ }^{1}$ Values for scenario 2 are given in parentheses when differing from scenario 1. Scenario 1: current situation in the Czech Republic (2005); scenario 2: expected situation in 2015.

crease in culling for health problems in scenario 2 necessitated a decrease in voluntary culling, so the number of calvings of Holstein cows improved slightly from scenario 1. In Czech Fleckviehs, a higher involuntary culling rate in scenario 2 was counterbalanced by improved fertility. Because the voluntary culling rate stayed the same, the average number of calvings of Czech Fleckvieh cows did not differ between scenario 1 and scenario 2.

The numbers of animals in the individual progeny categories are also shown in Table 8. In Holstein herds, almost no surplus heifers were available for sale, whereas in Czech Fleckvieh herds, about 10 heifers could be sold per 100 cows per year.

The marginal economic values for 18 evaluated traits are summarized in Table 9 for both scenarios and both breeds. The negative economic values for SCS, CM incidence, calving difficulty score, calf mortality, and fleshiness indicate that any numerical increase in mean value for these traits is economically detrimental. The mean class for fat covering has an optimum in fat class 3 within the $\mathrm{O}$ and $\mathrm{P}$ classes of the SEUROP carcass grading system (see Table 3). Thus, the economic value for a unit change in this trait was positive or negative according to the prior distribution of the bull, heifer, and cow carcasses of both breeds. Birth weight and mature weight of cows had negative economic values in both breeds, because increased weight resulted in increased feed costs for maintenance.

The relative importance of all traits for both scenarios and both breeds is shown in Table 10. These are the standardized economic values expressed as a percentage of the standardized economic value of 305-d milk yield. A substantial change in the relative economic importance of fat and protein percentages was observed between the 2 scenarios. Under the quota and milk pricing system in 2005, the relative economic value of milk protein percentage was near zero, and the economic value of fat percentage assumed negative values. With more emphasis on milk components in the milk

Table 6. Input variables for the calculation of revenues ${ }^{1}$

\begin{tabular}{|c|c|c|}
\hline Variable & Scenario 1 & Scenario 2 \\
\hline Upper limit for SCC in class 1 , number of somatic cells $/ \mathrm{mL}$ of milk & 250,000 & 250,000 \\
\hline Upper limit for SCC in class 2, number of somatic cells $/ \mathrm{mL}$ of milk & 400,000 & 400,000 \\
\hline Bonus for milk fat percentage, cents $/ \%$ of fat & 0.18 & 2.14 \\
\hline Bonus for milk protein percentage, cents $/ \%$ of fat & 0.36 & 4.29 \\
\hline Bonus for milk quality class 1 according to SCC, cents $/ \mathrm{kg}$ & 0.54 & 0.71 \\
\hline Heifers & 2.79 & 3.00 \\
\hline Cows & 2.60 & 2.60 \\
\hline Coefficient of decrease in carcass price for animals involuntarily culled & 0.8 & 0.8 \\
\hline Price of pregnant breeding heifers, $€ / \mathrm{kg}$ of live weight & $2.14(1.96)$ & $2.14(1.96)$ \\
\hline Price of male breeding calf, €/animal & $1,429(1,321)$ & $1,429(1,321)$ \\
\hline Price for dung, $€ / 100 \mathrm{~kg}$ & 0.54 & 0.54 \\
\hline
\end{tabular}

\footnotetext{
${ }^{1}$ If different values for Holsteins and Czech Fleckviehs were used, the values for Czech Fleckviehs are given in parentheses. Scenario 1: current situation in the Czech Republic (2005); scenario 2: expected situation in 2015.

${ }^{2}$ Monetary unit in the European Union: $€ 1=100$ cents.

${ }^{3}$ The best class for carcasses was class S1, with S being the best class for fleshiness and 1 being the best class for fat covering.
} 
Table 7. Input variables for the calculation of $\operatorname{costs}^{1}$

\begin{tabular}{|c|c|c|}
\hline Variable & Scenario 1 & Scenario 2 \\
\hline Price of semen from AI, €/insemination dose & $17.86(14.29)$ & $17.86(14.29)$ \\
\hline Price per reinsemination, $€$ & 5.36 & 5.36 \\
\hline \multicolumn{3}{|l|}{ Cost for removing and rendering dead animals, €/animal } \\
\hline Mature animals & 14.29 & 14.29 \\
\hline Young animals & 7.14 & 7.14 \\
\hline \multicolumn{3}{|l|}{ Cost for veterinary treatment } \\
\hline Cows, €/animal per reproduction cycle & $42.86(39.29)$ & $45.00(41.25)$ \\
\hline Reared calves, €/animal per rearing period & 2.25 & 2.36 \\
\hline Breeding heifers, €/animal until calving & 8.14 & 8.54 \\
\hline Animals in fattening, €/animal & 6.07 & 6.36 \\
\hline \multicolumn{3}{|l|}{ Veterinary cost connected with dystocia, €/calving } \\
\hline Calving score $3^{2}$ & 28.57 & 30.00 \\
\hline Calving score $4^{3}$ & 70.71 & 74.25 \\
\hline \multicolumn{3}{|l|}{ Herdsman's hours connected with dystocia, h/calving } \\
\hline Calving score 3 & 3 & 3 \\
\hline Calving score 4 & 5 & 5 \\
\hline Cost for drugs for mastitis, $€ /$ mastitis case & 11.43 & 12.00 \\
\hline Price of drugs for antibiotic drying cows, €/udder quarter & 2.14 & 2.25 \\
\hline Charge for veterinary service, $€ / h$ & 10.71 & 11.25 \\
\hline Value of herdsman's time, $€ / h$ & 5.00 & 5.25 \\
\hline Veterinarian's time for mastitis, $\mathrm{h} /$ mastitis case & 0.5 & 0.5 \\
\hline Herdsman's time ${ }^{4}$ for mastitis, $\mathrm{h} /$ mastitis case & 1 & 1 \\
\hline \multicolumn{3}{|l|}{ Fixed costs, ${ }^{5} € /$ animal per $d$} \\
\hline Cows & $2.32(2.14)$ & $2.68(2.46)$ \\
\hline Reared calves & 0.51 & 0.55 \\
\hline Breeding heifers & 0.34 & 0.38 \\
\hline Fattened bulls and heifers & 0.36 & 0.43 \\
\hline Price for water, $\operatorname{cents}^{6} / 100 \mathrm{~L}$ & 7.14 & 7.14 \\
\hline Price for straw for bedding, $€ / 100 \mathrm{~kg}$ & 0.54 & 0.54 \\
\hline Annual discount rate & 0.05 & 0.05 \\
\hline
\end{tabular}

\footnotetext{
${ }^{1}$ If different values for Holsteins and Czech Fleckviehs were used, the values for Czech Fleckviehs are given in parentheses. Scenario 1: current situation in the Czech Republic (2005); scenario 2: expected situation in 2015 .

${ }^{2}$ Calving score 3 was calving with veterinary assistance.

${ }^{3}$ Calving score 4 was calving with cesarean section.

${ }^{4}$ Time for treatment and separate milking, for example.

${ }^{5}$ Fixed costs included labor, energy, fuels, repairs, insurance, interest rate paid on capital investments, and overhead costs.

${ }^{6}$ Monetary unit in the European Union: $€ 1=100$ cents.
}

pricing system in 2015 , the protein percentage reached 37 to $38 \%$ of the economic importance of milk yield, whereas for fat percentage, the relative economic values were 27 to $31 \%$ of the value of milk yield. The relative economic values of the other traits increased slightly or stayed nearly unchanged when comparing scenario 2 with scenario 1 results.

Following 305-d milk yield, the second most important trait was SCS, reaching $32 \%$ to $43 \%$ of the importance of milk yield in both scenarios and for both breeds. Length of productive life of cows followed, with values similar to those of milk fat and milk protein percentages in scenario 2. Calf growth rate during the rearing and fattening periods reached about 10 to $15 \%$ of the importance of milk yield and showed only minor differences between scenarios and breeds.

The importance of fleshiness, fat covering, birth weight, and conception rate of heifers (compared with that of milk yield) was near zero in all calculations.
This was caused by small differences in price among the fleshiness and fat covering classes (see Table 3), the relatively high prices for culled heifers, and the already high conception rates in heifers. Cost savings from shortening the fattening period through a higher birth weight of calves were nullified by increasing the feed cost for higher maintenance of heavier animals.

The low economic importance of calf mortality relative to milk yield can be explained by the relatively small share of revenues for beef to total revenue per cow per year. Revenue from milk contributed 84 and $74 \%$ of the total revenues for Holstein and Czech Fleckvieh herds, respectively, in scenario 1 . For scenario 2, these proportions were 78 and $72 \%$ for the 2 breeds.

\section{DISCUSSION}

\section{Model for the Calculation of Economic Values}

Our bioeconomic model contains 4 main parts: 1) the calculation of the herd structure as the stationary state 
Table 8. Modeled herd structure for Holsteins $(\mathrm{H})$ and Czech Fleckviehs $(\mathrm{F})^{1}$

\begin{tabular}{lrrrrr}
\hline & \multicolumn{2}{c}{ Scenario 1} & & \multicolumn{2}{c}{ Scenario 2} \\
\cline { 2 - 3 } \cline { 5 - 6 } Variable & $\mathrm{H}$ & $\mathrm{F}$ & $\mathrm{H}$ & $\mathrm{F}$ \\
\hline Number of cows in lactation & & & & \\
1 & 36.47 & 29.29 & 34.40 & 29.34 \\
2 & 21.11 & 20.97 & 20.53 & 21.01 \\
3 & 12.47 & 12.98 & 12.50 & 12.95 \\
4 & 8.22 & 9.72 & 8.47 & 9.70 \\
5 & 5.98 & 7.48 & 6.33 & 7.47 \\
6 & 4.65 & 5.75 & 5.04 & 5.74 \\
7 & 3.70 & 4.60 & & 4.11 & 4.59 \\
8 & 2.98 & 3.67 & 3.39 & 3.67 \\
9 & 2.40 & 3.00 & 2.80 & 3.00 \\
10 & 2.02 & 2.53 & 2.41 & 2.53 \\
Number of calvings per cow & 2.74 & 3.41 & 2.91 & 3.41 \\
Number of calves born alive & 95.50 & 95.93 & 95.54 & 95.92 \\
Number of calves reared & 87.35 & 88.25 & 87.44 & 88.24 \\
Number of bulls fattened to target slaughter weight & 38.81 & 40.46 & 39.86 & 40.46 \\
Number of male calves sold for breeding & 0.43 & 0.22 & 0.44 & 0.22 \\
Number of heifers reared for replacement & 43.08 & 33.94 & 42.87 & 33.94 \\
Number of heifers sold pregnant & 0.79 & 10.35 & 1.05 & 10.35 \\
\hline
\end{tabular}

${ }^{1}$ All figures are per 100 cows per year. Scenario 1: current situation in the Czech Republic (2005); scenario 2: expected situation in 2015 .

of a Markov chain, 2) the calculation of a detailed profit function for the defined production system (normative approach), 3) the calculation of economic values for each evaluated trait, and 4) the application of the gene-flow technique to calculate the numbers of discounted expressions for maternal and direct trait effects for a group of breeding animals of interest (e.g., breeding bulls). The last part is described in the companion paper (Wolfová et al., 2007).
The use of Markov chain methodology to define transitions among cattle categories and for calculation of the stationary state of the herd allows the appropriate modeling of the impact of genetic changes in functional traits (length of productive life of cows, reproduction, and health traits) on the herd structure. This methodology is often used for modeling herd structure in decision support systems (Kristensen, 2003). Reinsch and Dempfle (1998) applied this approach to the calculation of

Table 9. Economic values (in € per unit of the trait and per cow per year) for Holsteins $(\mathrm{H})$ and Czech Fleckviehs (F) for both scenarios

\begin{tabular}{|c|c|c|c|c|}
\hline \multirow[b]{2}{*}{ Trait } & \multicolumn{2}{|c|}{$\mathrm{H}$} & \multicolumn{2}{|c|}{$\mathrm{F}$} \\
\hline & Scenario 1 & Scenario 2 & Scenario 1 & Scenario 2 \\
\hline $305-\mathrm{d}$ milk yield ${ }^{2} \mathrm{~kg}$ & 0.12 & 0.10 & 0.14 & 0.13 \\
\hline Milk fat percentage, $\%$ & -77.68 & 77.32 & -43.71 & 89.32 \\
\hline Milk protein percentage, $\%$ & -4.45 & 267.14 & -1.12 & 225.07 \\
\hline SCS & -309.68 & -323.43 & -261.71 & -310.29 \\
\hline Clinical mastitis incidence, cases/cow-year & -64.19 & -60.25 & -58.05 & -59.16 \\
\hline Calving difficulty, score & -156.93 & -46.36 & -216.64 & -226.43 \\
\hline Calf mortality at birth, $\%$ & -0.63 & -0.80 & -0.72 & -1.12 \\
\hline Calf mortality in rearing, $\%$ & -1.84 & -2.07 & -1.99 & -2.44 \\
\hline Conception rate of heifers, $\%$ & 0.97 & 0.84 & 0.62 & 0.56 \\
\hline Conception rate of cows, $\%$ & 4.60 & 4.61 & 3.30 & 3.25 \\
\hline Length of productive life of cows, yr & 74.14 & 63.36 & 58.39 & 57.29 \\
\hline Birth weight of calves, $\mathrm{kg}$ & -0.13 & -0.05 & -0.12 & -0.05 \\
\hline Mature weight of cows, $\mathrm{kg}$ & -0.58 & -0.51 & -0.53 & -0.39 \\
\hline Daily gain in the rearing period of calves, $\mathrm{g} / \mathrm{d}$ & 0.14 & 0.15 & 0.16 & 0.17 \\
\hline Daily gain in fattening, $\mathrm{g} / \mathrm{d}$ & 0.17 & 0.18 & 0.20 & 0.18 \\
\hline Dressing percentage, $\%$ & 8.07 & 8.89 & 8.97 & 9.61 \\
\hline Fleshiness, class & -55.57 & -60.43 & -49.25 & -52.75 \\
\hline Fat covering, class & 1.32 & 1.63 & -20.54 & -21.98 \\
\hline
\end{tabular}

${ }^{1}$ Scenario 1: current situation in the Czech Republic (2005); scenario 2: expected situation in 2015.

${ }^{2}$ Milk with given average fat and protein percentages. 
Table 10. Relative economic values of traits expressed as a percentage of the standardized economic value of milk yield for Holsteins (H) and Czech Fleckviehs (F) in both scenarios ${ }^{1}$

\begin{tabular}{|c|c|c|c|c|}
\hline \multirow[b]{2}{*}{ Trait } & \multicolumn{2}{|c|}{$\mathrm{H}$} & \multicolumn{2}{|c|}{$\mathrm{F}$} \\
\hline & Scenario 1 & Scenario 2 & Scenario 1 & Scenario 2 \\
\hline 305-d milk yield & 100 & 100 & 100 & 100 \\
\hline Milk fat percentage & -23 & 27 & -14 & 31 \\
\hline Milk protein percentage & -1 & 38 & 0 & 37 \\
\hline SCS & -35 & -43 & -32 & -40 \\
\hline Clinical mastitis incidence & -7 & -8 & -5 & -6 \\
\hline Calving difficulty & -12 & -4 & -15 & -17 \\
\hline Calf mortality at birth & -2 & -3 & -2 & -4 \\
\hline Calf mortality in rearing & -5 & -7 & -6 & -7 \\
\hline Conception rate of heifers & 2 & 2 & 1 & 1 \\
\hline Conception rate of cows & 12 & 15 & 9 & 10 \\
\hline Length of productive life of cows & 29 & 30 & 25 & 26 \\
\hline Birth weight of calves & 0 & 0 & 0 & 0 \\
\hline Mature weight of cows & -13 & -14 & -13 & 0 \\
\hline Daily gain in the rearing period of calves & 11 & 14 & 13 & 15 \\
\hline Daily gain in fattening & 11 & 13 & 13 & 13 \\
\hline Dressing percentage & 12 & 16 & 14 & 16 \\
\hline Fleshiness & -2 & -3 & -2 & -2 \\
\hline Fat covering & 0 & 0 & -1 & -1 \\
\hline
\end{tabular}

${ }^{1}$ Scenario 1: current situation in the Czech Republic (2005); scenario 2: expected situation in 2015.

economic values for health traits in cattle. The indirect effect of changes in functional traits on milk production, due only to changes in the age structure of the cow herd, may then be included in the calculation of economic values of the functional traits.

Stochastic simulation or dynamic programming models can be more precise than deterministic models, but they provide less insight into the calculation. Dynamic programming models are used especially when calculating economic values of functional traits (Boichard, 1990; Stott et al., 2005). They allow a reoptimization of management prior to calculating economic values. The optimization refers to culling strategy. Dekkers (1991) tested the hypothesis that economic values derived from situations that are suboptimal before or after the change in genetic merit, or both, may be biased. He found that economic values are robust to the degrees and types of suboptimality normally encountered in management policies. The model described here implies that the farmers' policies are optimal for the given economic and biological circumstances and that no improvement of animal performance is possible through a change in the management or feeding strategy. Further, it is expected that culling strategy will not change after a small improvement in a trait. In our opinion, there is very little room for voluntary culling at the present level of involuntary culling in dairy herds, and the annual response to selection in functional traits is expected to be very small, even when such traits are included in the breeding objective. The use of deterministic models without reoptimization of management policies after changing the level of functional traits will therefore cause only small biases. As Visscher et al. (1994) stated, it may be more useful, in practice, to have economic weights that are appropriate for the range of enterprise sizes and management practices actually occurring, rather than for a vaguely defined and unrealistic optimum herd size or management program.

For milk production traits, however, the level of which can change substantially through selection, the nutritional strategy at the farm should be optimized prior to calculating economic values for different milk production levels (e.g., for different breeds). Stott et al. (2005) stated that a reduction in average lactation yield from approximately 8,100 to $5,200 \mathrm{~kg}$ had little effect on any of their economic values, suggesting that they were suitable for use with other populations with different mean yields. In our calculation, production level had an important impact on the economic values of milk yield and mastitis incidence (compare Holsteins with Czech Fleckviehs in Table 9). We presume that the results of Stott et al. (2005) were caused by applying the same feeding rations (and the same feeding costs per kilogram of milk) and the same average costs of clinical mastitis per affected lactation for different levels of milk production. In spite of the same amount of energy and protein needed per kilogram of milk at different milk production levels, a feed ration with higher energy and protein density must be applied to high-producing cows to compensate for an inadequate increase in feed intake as milk production increases. Higher costs per case of mastitis are associated with higher milk production levels because more milk has to be discarded. 
The discounting procedure used to calculate present values of revenues and costs in the profit function allowed us to relate marginal economic values of all traits expressed in different animal categories at different times to the same base, that is, per cow per year to the time of birth of her calf. The number of discounted expressions (NDE) for revenues and costs in our calculations include only one generation of progeny. Therefore, these NDE cannot be compared with the NDE presented, for example, by Ponzoni and Newman (1989) or Amer et al. (2001). Their NDE include the number of animals over several generations during an investment period. In our model, the future generations are included separately when calculating the relative economic weights for maternal and direct components of a trait for a defined selection group of animals (e.g., bulls) using the gene-flow technique. The calculation of these relative economic weights is not presented here but in the accompanying paper (Wolfová et al., 2007).

\section{Economic Values of Traits}

Differences in production models, definitions of traits, and assumptions about management system effects on genetic improvement of particular traits make a direct comparison of economic values among different countries very difficult. The relative economic importance of traits calculated on the basis of standardized economic values depends very strongly on the genetic standard deviations of the traits, which may differ considerably among populations. Therefore, estimates of the genetic standard deviations for a particular breed and country should be used whenever possible.

In spite of the limitations cited above, some general statements about economic values can be derived from the literature and from the present study. Economic values of milk and fat yields generally are higher in situations without milk and fat output limitations than in situations with output limitations (Groen, 1989a,b; Pieters et al., 1997; Nielsen et al., 2004). Economic values for fat and protein percentages were presented in our study over fat and protein yields because of the milk pricing system in the Czech Republic (see the Materials and Methods section). But the recalculation of these economic values to the economic values for milk and protein yields is simple and straightforward.

Under marketing systems with quotas, the number of cows generally decreases as 305-d milk or milk fat yield are increased by direct or indirect selection. Some authors, however, have allowed for increasing the milk quota on the farm by purchasing quota (Gibson et al., 1992; Reinsch and Dempfle, 1998; Wünsch and Bergfeld, 2001). When calculating economic values of traits for a national breeding program, however, the whole dairy cattle population must be taken into account, making it impossible to accommodate quota purchasing. In the European Union, the trade of quotas between the member states is not expected in the next $10 \mathrm{yr}$.

The relative importance of milk production traits (milk yield, fat, and protein) is very sensitive to the payment system (Gibson, 1989) and to assumptions about the future global conditions (the maintenance or revocation of quotas for milk yield and fat percentage in the European Union, for example). In most European countries, economic values for production traits were reestimated in the 1990s after introduction of the milk quota. In situations in which both fat and protein percentages were included in the payment system, the relative economic values for fat and protein yields (or percentages) varied under quota systems from 1:3 (Miesenberger, 1997) to 1:20 (Steverink et al., 1994), in comparison with the scenarios without quotas, where the relation varied from 1:1.3 (Beard, 1992) to 1:3.2 (Wolfová et al., 2001). Even negative economic values were obtained for fat yield in quota systems (Pieters et al., 1997; present investigation). Assumptions made about the milk quota and the milk pricing system in the year 2015 in the Czech Republic are, however, uncertain because political decisions often have more impact on the production circumstances and milk prices than the actual market conditions or consumer requirements.

Among functional traits, SCS showed the highest standardized economic values in our study (-€22.50 to $-€ 27.50$ ). A somewhat lower value was reported by Boettcher et al. (1998) for Canadian conditions (-€18.75 when summing over all lactations). The standardized economic values calculated for $\mathrm{CM}$ incidence in the present study (-€3.72 to $-€ 5.14$ per genetic standard deviation) were lower than the appropriate values published by Toivakka et al. (2005) for Finnish Holsteins (-€20.75) or by Boettcher et al. (1998) for Canadian conditions (-€16.07 for CM when summing over all lactations).

Other than in CM and SCS, where the economic values depend only on costs or only on revenues, the economic values of reproduction traits or longevity depend strongly on the ratio of revenues and costs for each cattle category. For example, decreasing stillbirth or calf losses and increasing the conception rate of females or length of productive life of cows or both yields more calves for fattening or selling. Improving these traits resulted in positive economic values only when revenues from fattened or sold animals exceeded the costs of raising these animals. This may explain the relatively low economic values for some functional traits reported in the literature (Pärna et al., 2002; Nielsen et al., 2004). 
Changing the length of the productive life of cows influences all production traits, for example, milk yield (through age structure of the herd), number of calves available for selling or fattening, revenues from culled cows, and costs for involuntary culling. Much more than the economic values of other traits, its economic value therefore depends on the relationships between revenues and costs, on the current mean value of the trait, and on the milk production level. As a consequence, large differences in the economic value for length of productive life of cows can be found in the literature (e.g., €0.095/d in Reinsch and Dempfle, 1998, or €1.12/ $\mathrm{d}$ in Toivakka et al., 2005).

Among the beef production traits, the mature weight of cows has most often been evaluated in dairy cattle populations, generally having a negative economic value (Visscher et al., 1994; González-Recio et al., 2004). Growth and carcass traits are evaluated mainly in dualpurpose cattle breeds. Their relative importance ranges from strongly positive to negative (Miesenberger et al., 1998; Pärna et al., 2002).

\section{CONCLUSIONS}

Changes in dairy cattle production circumstances in the year 2015 in the European Union will substantially influence the relative importance of milk production traits in the breeding goal of the Czech dairy cattle population. The milk pricing system is the most important factor affecting the relative weighting of milk volume, fat and protein percentages, $\mathrm{CM}$ incidence, and SCS in the breeding objective. Uncertainty in the milk pricing system should therefore be taken into account when defining the breeding goal. Somatic cell count should be included in the breeding goal. In the future, more emphasis should be given to length of productive life and reproductive performance (conception rate, calving difficulty score) of cows. Regarding carcass and meat quality, traits should be identified that are more predictive of profit from the production system than fleshiness and fat covering classes.

Although the impact of some traits on farm profit was estimated to be very low, it must be taken into account that the economic value of a trait estimated in the present manner does not include the correlated economic impact on other traits. The contribution of a trait in the breeding goal to the total monetary gain from a breeding program should be estimated using selection index theory before deciding on its inclusion in or rejection from the breeding goal.

\section{ACKNOWLEDGMENTS}

The authors would like to thank D. Bureš, L. Bartoň, R. Zahrádková, and J. Přibyl from the Institute of Ani- mal Science Prague-Uhříněves for their helpful comments and the Czech Fleckvieh Breeders Association and the Holstein Cattle Breeders Association of the Czech Republic for making data available. Furthermore, the technical assistance of P. Mrázková is acknowledged. Special thanks are extended to W. D. Hohenboken (Corvallis, Oregon) who not only edited the English of the paper but also contributed helpful comments. The research project was supported by the Ministry of Agriculture of the Czech Republic (MZE0002701401).

\section{REFERENCES}

AFCR. 1993. Energy and Protein Requirements of Ruminants (advisory manual prepared by the AFRC Technical Committee on Responses to Nutrients), CAB International, Wallingford, UK.

Amer, P. R., G. Simm, M. G. Keane, M. G. Diskin, and B. W. Wickham. 2001. Breeding objectives for beef cattle in Ireland. Livest. Prod. Sci. 67:223-239.

Beard, K. T. 1992. Studies on breeding objectives and selection indices applicable to the Australian dairy cattle industry. PhD Thesis. University of New South Wales, Sydney, Australia.

Boettcher, P. J., J. C. M. Dekkers, and B. W. Kolstad. 1998. Development of an udder health index for sire selection based on somatic cell score, udder conformation, and milking speed. J. Dairy Sci. 81:1157-1168.

Boichard, D. 1990. Estimation of the economic value of conception rate in dairy cattle. Livest. Prod. Sci. 24:187-204.

Cranford, J. L., and R. E. Pearson. 2001. Relationships of sire predicted transmitting ability for somatic cell score with measures of daughter performance. J. Dairy Sci. 84:1501-1507.

Dědková, L., and J. Wolf. 2001. Estimation of genetic parameters for milk production traits in Czech dairy cattle populations. Czech J. Anim. Sci. 46:292-301.

Dekkers, J. C. M. 1991. Estimation of economic values for dairy cattle breeding goals-Bias due to sub-optimal management policies. Livest. Prod. Sci. 29:131-149.

Fox, D. G., C. J. Sniffen, J. D. O'Connor, J. B. Russell, and P. J. Van Soest. 1990. A model for predicting cattle requirements and feedstuff utilization. Pages 7-83 in The Cornell Net Carbohydrate and Protein System for Evaluation of Cattle Diets. Cornell Univ. Agr. Exp. Sta. No. 34. Cornell University, Ithaca, NY.

Gibson, J. P. 1989. The effect of pricing systems, economic weights, and population parameters on economic response to selection on milk components. J. Dairy Sci. 72:3314-3326.

Gibson, J. P., N. Graham, and E. B. Burnside. 1992. Selection indexes for production traits of Canadian dairy sires. Can. J. Anim. Sci. $72: 477-491$

González-Recio, O., M. A. Pérez-Cabal, and R. Alenda. 2004. Economic value of female fertility and its relationship with profit in Spanish dairy cattle. J. Dairy Sci. 87:3053-3061.

Groen, A. F. 1989a. Economic values in cattle breeding. I. Influences of production circumstances in situations without output limitations. Livest. Prod. Sci. 22:1-16.

Groen, A. F. 1989b. Economic values in cattle breeding. II. Influences of production circumstances in situations with output limitations. Livest. Prod. Sci. 22:17-30.

Groen, A. F. 1990. Influences of production circumstances on the economic revenue of cattle breeding programmes. Anim. Prod. $51: 469-480$.

Heringstad, B., G. Klemetsdal, and T. Steine. 2003. Selection responses for clinical mastitis and protein yield in two Norwegian dairy cattle selection experiments. J. Dairy Sci. 86:2990-2999.

Houben, E. H. P., A. A. Dijkhuizen, J. A. M. van Arendonk, and R. B. M. Huirne. 1993. Short-term and long-term production losses and repeatability of clinical mastitis in dairy cattle. J. Dairy Sci. 76:2561-2578. 
Hradecká, E. 2002. Odhady plemenné hodnoty pro obtížnost telení. $\mathrm{PhD}$ Thesis Jihočeská Univerzita, České Budějovice.

Kristensen, A. R. 2003. A general software system for Markov decision processes in herd management applications. Comput. Electron. Agric. 38:199-215.

Kvapilík, J. 2005. Konstrukce nákupních cen mléka v českých a západoevropských mlékárnách. VƯZV, Praha, Czech Republic.

Kvapilík, J., J. Pytloun, and P. Buček. 2006. Ročenka Chov skotu v Ceské republice. Ceskomoravská společnost chovatelů, a.s. Praha, Czech Republic.

Miesenberger, J. 1997. Zuchtzieldefinition und Indexselektion für die österreichische Rinderzucht. $\mathrm{PhD}$ Thesis Universität für Bodenkultur, Wien, Austria.

Miesenberger, J., J. Sölkner, and A. Essl. 1998. Economic weights for fertility and reproduction traits relative to other traits and effects of including functional traits into a total merit index. Interbull Bull. 18:78-84.

Miglior, F., B. L. Muir, and B. J. Van Doormaal. 2005. Selection indices in Holstein cattle of various countries. J. Dairy Sci. 88:1255-1263.

Nielsen, H. M., A. Groen, J. Pedersen, and P. Berg. 2004. Stochastic simulation of economic values and their standard deviations for production and functional traits in dairy cattle under current and future Danish production circumstances. Acta Agric. Scand., Anim. Sci. 54:113-126.

Olesen, I., A. F. Groen, and B. Gjerde. 2000. Definition of animal breeding goals for sustainable production systems. J. Anim. Sci. 78:570-582.

Páchová, E., L. Zavadilová, and J. Sölkner. 2005. Genetic evaluation of the length of productive life in Holstein cattle in the Czech Republic. Czech J. Anim. Sci. 50:493-498.

Pärna, E., O. Saveli, and T. Kaart. 2002. Economic weights for production and functional traits of Estonian Holstein population. Proc. 7th World Congr. Genet. Appl. Livest. Prod. (CD-ROM). Communication no. 01-68. INRA, Paris, France.

Petrikovič, P., and A. Sommer. 2002. Potreba živín pre hovädzí dobytok. VÚŽV, Nitra, Slovak Republic.

Philipsson, J., and B. Lindhé. 2003. Experiences of including reproduction and health traits in Scandinavian dairy cattle breeding programmes. Livest. Prod. Sci. 83:99-112.

Pieters, T., F. Canavesi, M. Cassandro, E. Dadati, and J. A. M. van Arendonk. 1997. Consequences of differences in pricing systems between regions on economic values and revenues of a national dairy cattle breeding scheme in Italy. Livest. Prod. Sci. 49:23-32.

Ponzoni, R. W., and S. Newman. 1989. Developing breeding objectives for Australian beef cattle production. Anim. Prod. 49:35-47.

Přibyl, J., P. Šafus, M. Štípková, L. Stádník, and V. Čermák. 2004. Selection index for bulls of Holstein cattle in the Czech Republic. Czech J. Anim. Sci. 49:244-256.

Reinsch, N. 1993. Berechnung wirtschaftlicher Gewichtungsfaktoren für sekundäre Leistungsmerkmale beim Fleckvieh. $\mathrm{PhD}$ Thesis. Technische Universität München-Weihenstephan, Germany.

Reinsch, N., and L. Dempfle. 1998. Investigations on functional traits in Simmental: 3. Economic weights at the stationary state of a Markov chain. Arch. Tierz. 41:211-224.
Roffeis, M., and H. Brudel. 2003. Untersuchungen zu Produktionsvoraussetzungen, Produktionsleistungen und Wirtschaftlichkeit in der Jungbullenmast des Landes Brandenburg. Landesamt für Verbraucherschutz und Landwirtschaft, Frankfurt, Germany.

Sölkner, J., J. Miesenberger, A. Willam, C. Fuerst, and R. Baumung. 2000. Total merit indices in dual purpose cattle. Arch. Tierz. 43:597-608.

Sonnleitner, G. 2006. Milchproduktion in Deutschland hat Zukunft. Page 2 in Märkte heute und morgen. Sonderdruck 12. ZMPMilchforum, Berlin, Germany. ZmP GmbH, Bonn, Germany.

Steverink, M. H. A., A. F. Groen, and P. B. M. Berentsen. 1994. The influence of restricting nitrogen losses of dairy farms on dairy cattle breeding goals. Neth. J. Agric. Sci. 42:21-27.

Stott, A. W., M. P. Coffey, and S. Brotherstone. 2005. Including lameness and mastitis in a profit index for dairy cattle. Anim. Sci. 80:41-52.

SZIF (State Agricultural Intervention Fund of the Czech Republic). 2006. Hovězí a vepřové maso, Bulletin 1_2006. http://www.szif.cz/ irj/portal Accessed May 21, 2006.

Toivakka, M., J. I. Nousiainen, and E. A. Mäntysaari. 2005. Estimation of economic values of longevity and other functional traits in Finnish dairy cattle. Paper CG2.25 in 56th Ann. Mtg. EAAP, Uppsala, Sweden. Wageningen Acad. Publ., Wageningen, the Netherlands.

Vencl, B., Z. Frydrych, A. Krása, R. Pospíšil, J. Pozdíšek, A. Sommer, M. Sime, and L. Zeman. 1991. Nové systémy hodnocení krmiv pro skot. Akademie zemědělsky̌ch věd ČSFR. Praha, Czech Republic.

Visscher, P. M., P. J. Bowman, and M. E. Goddard. 1994. Breeding objectives for pasture based dairy production systems. Livest. Prod. Sci. 40:123-137.

Wolf, J., M. Wolfová, and E. Krupa. 2005. User's Manual for the Program ECOWEIGHT (C programs for calculating economic weights in livestock), Version 2.0.18. Research Institute of Animal Production Prague-Uhříněves, Czech Republic, and Research Institute of Animal Production Nitra, Slovak Republic.

Wolfová, M., J. Přibyl, and J. Wolf. 2001. Economic weights for production and functional traits of Czech dairy cattle breeds. Czech J. Anim. Sci. 46:421-432.

Wolfová, M., M. Štípková, and J. Wolf. 2006. Incidence and economics of clinical mastitis in five Holstein herds in the Czech Republic. Prev. Vet. Med. 77:48-64.

Wolfová, M., J. Wolf, and J. Hyánek. 1995. Economic weights for beef production traits in the Czech Republic. Livest. Prod. Sci. 43:63-73.

Wolfová, M., J. Wolf, J. Kvapilík, and J. Kica. 2007. Selection for profit in cattle. II. Economic weights for dairy and beef sires in crossbreeding systems. J. Dairy Sci. 90:2456-2467.

Wolfová, M., J. Wolf, J. Přibyl, R. Zahradková, and J. Kica. 2005. Breeding objectives for beef cattle used in different production systems: 1. Model development. Livest. Prod. Sci. 95:201-215.

Wünsch, U., and U. Bergfeld. 2001. Berechnung wirtschaftlicher Gewichte für ökonomisch wichtige Leistungsmerkmale in der Milchrinderzucht. Züchtungskunde 73:3-11. 